\title{
Action Research and Active Learning in Indonesia: An Introduction to the Special Issue
}

In recent decades research has increasingly become an integral part of the mission of universities the world over. While this has long been true of those institutions designated as research universities, it is increasingly the case with those that have traditionally seen their mission as teaching as well. This expansion of the research mission is due to a number of factors. At its heart, of course, is the long held belief that the pursuit of knowledge for the sake of knowledge is a worthwhile human endeavor. But universities, and the governments that support them, have come to see the tremendous benefits of research at all levels to advancing science, improving human well-being, informing public policy, solving practical problems and fostering economic development. Even the ancient practice of teaching is now acknowledged to be inextricably intertwined with inquiry, both for its utility in helping to improve teaching practice and for its contribution to the development of learners who are themselves inquirers, an attribute that is indispensable in increasingly knowledge-based, democratic societies.

Educational leaders in the Republic of Indonesia recognize the growing importance of research and have taken steps to ensure that Indonesian universities enhance their research capacity in the service of the Indonesian people. In his Foreword to the Higher Education Long Term Strategy, 2003-2010, then Director General of Higher Education Satryo Soemantri Brodjonegoro wrote "The impact of globalization causes a shifting role of higher education institutions from traditional learning institutions to knowledge creators" (Directorate General of Higher Education 2003, 1). Because this role of "knowledge creator" is seen to be so important to sustained economic growth, the Higher Education Long Term Strategy, 2003-2010 established the goals of creating research and graduate programs in Indonesian universities that would serve as "the incubators for the development of the capabilities to foster an adaptable, sustainable, knowledge-based economy," of promoting international collaboration in research, and fostering cooperation among Indonesian universities in their teaching and research activities (Directorate General of Higher Education 2003, 2).

The Directorate's strategic plan acknowledges, however, the challenges to achieving these goals. Research infrastructure, equipment and funding for research remain severely limited at most Indonesian universities. Collaboration between institutions is uncommon. Even internal cross-department, interdisciplinary collaborations within institutions are rare, resulting in "isolated discipline-based teaching and research [that is] unable to comprehensively respond to the real world trend of merging disciplines and fields" (Directorate General of Higher Education 2003, 21). More recent international assessments of the state of Indonesian higher education confirm the Directorate's mapping of the sector's challenges and needed future directions, calling for development of the human resources necessary to conduct applied research and providing lecturers with opportunities for research "through professional guidance and training programs that address weaknesses identified by students and the lecturers themselves" (Evans et al. 2009a; Evans et al. 2009b, 52). Clearly, development of Indonesian lecturers' capacity to conduct high quality research is an important goal for the Directorate General of Higher Education and its international supporters.

\section{The Action Research Project}

The eight articles published here in this special issue of Excellence in Higher Education, and the long-term collaboration that led to them, embody many of the goals and recommendations outlined above. They are the fruit of a five-year, international effort of United States and Indonesian university faculty members to enhance the capacity of Indonesian university lecturers to conduct action research. The project engaged an interdisciplinary group of, at times, almost 100 lecturers representing eight Indonesian universities in training for and carrying out a collaborative action research project in four separate provinces. In the process, we took important steps toward fostering the sort of international, inter-institutional, interdisciplinary research into real-world problems envisioned in the Directorate General of Higher Education's strategic plan.

Our action research project began in 2006 with an invitation from the Education Development Center, prime contractor for component two of the USAID-funded project Decentralized Basic Education, to work with them and two other US university partners - the University of Pittsburgh and the University of Massachusetts at Amherst - to enhance the capacity of Indonesian 
university faculties of education to support the improvement of provincial primary education. That same year, my colleague, King D. Beach, and I travelled to Indonesia to meet with lecturers and administrators at eight universities: The Open University of Jakarta, Sultan Ageng Tirtayasa University in Banten, the State University of Medan and State Islamic Studies Institute in North Sumatra, and Muhammadiyah University, Syiah Kuala University, and the State Islamic Studies Institute Ar-Raniry in Aceh. During the course of our initial discussions about possible areas of collaboration, it became clear that action research was an interest across all eight institutions. Classroom action research had been introduced and disseminated widely in the course of an earlier professional development project as a technique that classroom teachers could use to improve their teaching practice. As a result, education lecturers were expected to teach classroom action research, but many had not been trained in classroom action research themselves, and most had no experience conducting action research. We began, therefore, with an agreement to provide training in action research, but with a view toward demonstrating its usefulness as a research strategy beyond the classroom.

Our trainings began with workshops in the summer of 2007 designed to introduce basic concepts associated with action research-multiple cycles of data gathering and analysis, the idea of using systematic inquiry to improve practice, et cetera-and to train participants in data collection techniques: semi-structured interviews, focus group discussions and classroom observations. These workshops were followed up with trainings conducted in 2008 on the analysis of data and 2009 on preparing the results of an action research project for presentation at a scholarly conference and, eventually, publication in an academic journal. What had originally been conceived as a fairly straightforward workshop on action research, however, soon evolved into a large, multi-institutional, multi-province, interdisciplinary action research project in its own right. We decided to teach action research by doing action research with our Indonesian colleagues.

To this end, we organized our workshop participants in each province into two teams to investigate the implementation of teaching for active learning - an element of the DBE2 training provided to teachers in each province - in at least one state elementary school (sekolah dasar) and one state elementary madrasah (madrasah ibtidâ'iyah negeri) in each province. We provided each team with digital voice and video recorders for use in collecting and managing data. We also arranged for research funding and negotiated subcontracts with our university partners to provide them with the financial support they needed to carry out the research as well as the experience of managing research budgets. In this fashion we hoped to move our colleagues beyond a narrow conception of action research as something done only by individual teachers in their own classrooms to an understanding of action research as a methodology with collaborative, long-term applications beyond the classroom.

In an effort to make a virtue of a necessity, we attempted to use the unavoidably long gaps between workshops as opportunities for participants to practice what they had learned in the workshops: after the first workshop the teams would conduct multiple cycles of data collection so that they would have data they could use to practice what they learned in the second workshop on data analysis. Then, by the time the third workshop took place, each team would have data results that they were ready to prepare for presentation and publication. While this did not work exactly as planned - other responsibilities unavoidably drew participants' attention so research activity tended to wane between workshops - the teams remained relatively intact and participants remained focused on the objectives of their research over the life of the project.

After the final workshops focusing on conference presentation and writing for publication, the Florida State University team organized a two-day national conference on action research and active learning which was held on the campus of the Open University in December of 2009. At this conference, attended by more than 200 individuals from around Indonesia, the action research teams presented the results of their investigations before their colleagues on the other research teams as well as fellow lecturers and administrators from other universities around the country. This was an invaluable opportunity for the team members to receive critical feedback on their work as well as an opportunity for them to judge the thoroughness of that work against the efforts of their colleagues on the other teams. The presenters from the eight action research teams came away from the conference with a sense of pride in the work they had done and a renewed enthusiasm for both continuing their research and building on the network of researchers that had come together in the course of the project. Conference attendees began making requests for similar training at their own institutions.

After the conference, each team composed drafts of the articles published in this volume. Each draft was sent out for double-blind review by members of the international editorial board of Excellence in Higher Education. Each draft was extensively revised in response to reviewers' comments and then carefully edited before being published in this issue. The articles you see here, therefore, are not simply the products of a series of training workshops. They are the fruits of a long, rigorous, sustained collaborative inquiry that have met the international standard for quality research: anonymous peer review. They have earned their place in this scholarly journal. More importantly, however, they 
offer important insight into the effort to improve Indonesian education by equipping teachers and lecturers with skills essential to the exercise of their own professional autonomy, insight into Indonesian educational experience that only a team of Indonesian researchers could provide. Thus they constitute a valuable contribution to the international research literature on teaching for active learning and action research.

In conclusion, on behalf of myself and my colleagues at Florida State University who participated in various aspects of the DBE2 Project-King Beach, Mike Spector, Tom Luschei, and Flavia Ramos-Mattoussi, I would like to express our deep appreciation to USAID and the Education Development Center for the opportunity to participate in this project. But most of all, we thank our Indonesian friends and colleagues whose warmth and hospitality made our work in Indonesia such a pleasure and whose insight and intelligence are reflected in this issue of Excellence in Higher Education. We congratulate you on your success.

\section{References}

Directorate General of Higher Education. 2003. Higher Education Long Term Strategy, 2003-2010. Jakarta: Ministry of National Education, Republic of Indonesia.

Evans, David, Cornelia Flora, Gary Goodpastor, Peter Shepherd, and Kenneth Tolo. 2009a. Assessment of Higher Education Institutional Capacity in Selected Geographic and Subject Areas. Washington, DC: USAID.

Evans, David, Sean Tate, Richard Navaro, and Martina Nicolls. 2009b. Teacher Education and Professional Development in Indonesia: A Gap Analysis. Washington, DC: USAID.

Jeffrey Ayala Milligan

Professor and Director, Center for International Studies in Educational Research and Development, Learning Systems

Institute, Florida State University 